\title{
Istaroxime Inhibits Motility and Down- Regulates Orai1 Expression, SOCE and FAK Phosphorylation in Prostate Cancer Cells
}

\author{
Matias Julian Stagno ${ }^{\mathrm{a}}$ Nefeli Zacharopoulou ${ }^{\mathrm{b}}$ Jonas Bochem ${ }^{\mathrm{a}}$ \\ Anna Tsapara ${ }^{b}$ Lisann Pelzlc Tamer al-Maghout ${ }^{c}$ Galatea Kallergi ${ }^{b}$ \\ Saad Alkahtani ${ }^{b, d}$ Konstantinos Alevizopoulos ${ }^{e}$ Konstantinos Dimas $^{f}$ \\ Theodora Calogeropouloug Steven W. Warmann ${ }^{\mathrm{a}}$ Florian Langh,i Evi Schmid ${ }^{\mathrm{a}}$ \\ Christos Stournaras ${ }^{b}$
}

aDepartment of Pediatric Surgery \& Pediatric Urology, Children's Hospital, Eberhard-Karls-University

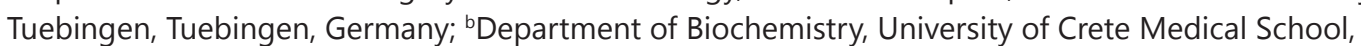
Voutes, Heraklion, Greece; 'Department of Internal Medicine III Eberhard-Karls-University, Tuebingen, Germany; 'Department of Zoology, Science College, King Saud University, Riyadh, Saudi Arabia; ${ }^{\text {eVentac }}$ Partners, Yverdon-les-Bains, Switzerland; fLaboratory of Pharmacology, Faculty of Medicine, University of Thessaly, Larissa, Greece; IInstitute of Biology, Medicinal Chemistry and Biotechnology, National

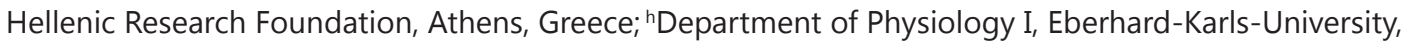
Tuebingen, Germany; 'Department of Molecular Medicine II, Medical Faculty, Heinrich Heine University, Duesseldorf, Germany

Key Words

Istaroxime $\bullet$ DU-145 prostate cancer cells $\bullet$ Orai1 $\bullet$ SOCE $\bullet$ FAK $•$ Migration

\begin{abstract}
Background/Aims: Istaroxime is a validated inotropic $\mathrm{Na}^{+} / \mathrm{K}^{+}$ATPase inhibitor currently in development for the treatment of various cardiac conditions. Recent findings established that this steroidal drug exhibits potent apoptotic responses in prostate tumors in vitro and in vivo, by affecting key signaling orchestrating proliferation and apoptosis, such as C-Myc and caspase 3, Rho GTPases and actin cytoskeleton dynamics. In the present study we examined whether istaroxime is affecting cell motility and analyzed the underlying mechanism in prostate tumor cells. Methods: Migration was assessed by transwell and wound healing assays, Orai1 and Stim1 abundance by RT-PCR and confocal immunofluorescence microscopy, Fura-2 fluorescence was utilized to determine intracellular $\mathrm{Ca}^{2+}$ and Western blotting for FAK/pFAK measurements. Results: We observed strong inhibition of cell migration in istaroxime treated DU-145 prostate cancer cells. Istaroxime further decreased Orai1 and Stim1 transcript levels and downregulated Orai1 protein expression. Moreover, SOCE was significantly decreased upon istaroxime treatment. Furthermore, istaroxime strikingly diminished phosphorylated FAK levels. Interestingly, the efficacy of istaroxime on the inhibition of DU-145 cell migration
\end{abstract}

M.J. Stagno and N. Zacharopoulou contributed equally and thus share first authorship.

E. Schmid and C. Stournaras contributed equally and thus share last authorship.

\begin{tabular}{ll}
\hline Prof. Dr. Christos Stournaras & $\begin{array}{l}\text { Department of Biochemistry, University of Crete Medical School, } 70013 \text { Heraklion } \\
\text { (Greece) } \\
\text { E-Mail stournac@uoc.gr }\end{array}$
\end{tabular}


Stagno et al.: Istaroxime Inhibits Migration in Prostate Cancer Cells

was further enhanced by blocking Orai1 with 2-APB and FAK with the specific inhibitor PF00562271. These results provide strong evidence that istaroxime prevents cell migration and motility of DU-145 prostate tumor cells, an effect at least partially attributed to Orai1 downregulation and FAK de-activation. Conclusion: Collectively our results indicate that this enzyme inhibitor, besides its pro-apoptotic action, affects motility of cancer cells, supporting its potential role as a strong candidate for further clinical cancer drug development.

(C) 2017 The Author(s)

Published by S. Karger AG, Basel

\section{Introduction}

Istaroxime is a novel drug candidate derived from a new generation of steroidal $\mathrm{Na}^{+} /$ $\mathrm{K}^{+}$ATPase enzyme inhibitors that has successfully finalized phase II clinical trials in patients with cardiac failure [1-3]. Recent experimental evidence points to a novel role of ion channels and especially of $\mathrm{Na}^{+} / \mathrm{K}^{+}$ATPase as potential anti-cancer targets. Indeed, expression of $\mathrm{Na}^{+} /$ $\mathrm{K}^{+}$ATPase subunits has been observed in various cancer types, while different, recently developed steroid-inhibitors of this enzyme have shown potent inhibitory activities in various previous studies [reviewed in [4, 5]].

Based on these reports, our group addressed previously the anti-cancer potential of various $\mathrm{Na}^{+} / \mathrm{K}^{+}$ATPase inhibitors [6, 7], showing strong activity in multiple cancer cell lines in vitro, as well as in prostate and lung cancer xenografts in vivo $[8,9]$. Focusing on istaroxime we demonstrated in a more recent study strong anti-cancer activity of this compound acting through caspase-3, c-Myc, actin reorganization and RhoA signaling in various cancer cell lines in vitro, as well as in prostate cancer xenografts in vivo [10].

However, although pro-apoptotic responses to istaroxime were clearly demonstrated, the profound anti-tumorigenic action of this compound has not been functionally correlated to other key tumor specific mechanisms, including Orai1 expression as well as cell motility and invasiveness. Indeed, cell proliferation, migration and cell death are frequently controlled by alterations of cytosolic $\mathrm{Ca}^{2+}$ activity [11-13], which in turn is regulated by the pore forming $\mathrm{Ca}^{2+}$ channel subunit Orai1 accomplishing store operated $\mathrm{Ca}^{2+}$ entry (SOCE) [14-19]. In line with this, Orai1 expression seems to be crucial for several tumor cell responses including cell proliferation, migration and apoptosis in various tumors [18, 20-22]. Based on these reports, in the present work we examined the migratory potential of prostate tumor cells following treatment with istaroxime and we evaluated the molecular signaling pathways involved. Our findings indicate that istaroxime blocked migration and invasiveness of DU-145 prostate tumor cells, an effect mainly associated with Orai1/Stim1 down-regulation, SOCE inhibition and FAK de-phosphorylation. These results provide novel mechanistic insights into the regulation of the anti-migratory potential of istaroxime in prostate tumors.

\section{Material and Methods}

\section{Cell lines and culture conditions}

The cell line DU-145 was cultured in RPMI 1640, supplemented with 1\% penicillin/streptomycin (Biochrom, Berlin, Germany) and 10\% fetal bovine serum (FCS, Biochrom, Berlin, Germany) in a humidified atmosphere containing $5 \% \mathrm{CO}_{2}$ at $37^{\circ} \mathrm{C}$. All cells were tested to be mycoplasma negative.

\section{RNA isolation and Real time PCR}

Real-time PCR (RT-PCR) experiments were performed in six-well plates with $3 \times 10^{5}$ DU-145 cells. Cells were harvested after treatment without or with istaroxime $(1.25$ and $2.5 \mu \mathrm{M})$ for 4 and 6 hours. RNA was isolated using the RNeasy mini kit by following the manufacturer's instructions (Qiagen). cDNA synthesis was performed using High capacity cDNA Reverse Transcription Kit (Applied Biosystems, Waltham, Massachusetts, USA).

Polymerase chain reaction (PCR) amplification of the respective genes was set up in a total volume of $20 \mu \mathrm{l}$ using $40 \mathrm{ng}$ of cDNA, $500 \mathrm{nM}$ forward and reverse primer and 2x GoTaq ${ }^{\circledR}$ qPCR Master Mix (Promega Corporation, Madison, WI, USA) according to the manufacturer's protocol. Cycling conditions were as 


\section{Cellular Physiology Cell Physiol Biochem 2017;42:1366-1376 \begin{tabular}{ll|l} 
and Biochemistry 10.1159/000479200 & $\begin{array}{l}\text { (C) 2017 The Author(s). Published by S. Karger AG, Basel } \\
\text { www.karger.com/cpb }\end{array}$
\end{tabular}}

Stagno et al.: Istaroxime Inhibits Migration in Prostate Cancer Cells

follows: initial denaturation at $95^{\circ} \mathrm{C}$ for 5 minutes, followed by 40 cycles of $58^{\circ} \mathrm{C}$ for 30 seconds and $72^{\circ} \mathrm{C}$ for 20 seconds. For the amplification the following primers were used ( $5^{`}-3$ `orientation):

Orai1, fw TGATGAGCCTCAACGAGCACTCCATG;

Orai1, rev TGCTGATCATGAGCGCAAACAGGTG;

STIM1, fw CCTGTGGAAGGCATGGAAGT;

STIM1, rev CTGAGGCAGCTCCACATATGT;

TBP, fw GCC CGA AAC GCC GAA TAT;

TBP, rev CCG TGG TTC GTG GCT CTC.

Specificity of PCR products was confirmed by analysis of a melting curve. Real-time PCR amplifications were performed on a CFX96 Real-Time System (Bio-Rad). All experiments were done in duplicate. Amplification of the house-keeping gene tbp (TATA binding protein) was performed to standardize the amount of sample RNA. Relative quantification of gene expression was achieved using the $\Delta$ ct method as described earlier [22-25].

\section{Western Blotting}

After the required treatment with istaroxime $(1.25$ and $2.5 \mu \mathrm{M})$, cells were washed with ice cold phosphate-buffered saline (PBS), followed by lysis in cell lysis buffer (Cell Signaling Technology, Inc., New England Biolabs). The extracts were centrifuged at $13,000 \mathrm{rpm}$ for $20 \mathrm{~min}$ at $4^{\circ} \mathrm{C}$, the protein concentration of the supernatant was determined and the sample buffer for SDS-PAGE was added. $30 \mu \mathrm{g}$ protein per lane were separated by $10 \%$ SDS-PAGE and transferred to nitrocellulose membrane (VWR). Nonspecific binding was blocked by incubation with $10 \%$ nonfat dry milk in phosphate-buffered saline containing $0.1 \%$ Tween-80. Subsequently, membranes were incubated with a rabbit monoclonal FAK antibody (1:1000, Cell Signaling Technology, Inc., New England Biolabs, $125 \mathrm{kDa}$ ) or with rabbit polyclonal phospho-FAK (Y397) antibody (1:500, Cell Signaling Technology, Inc., New England Biolabs, $125 \mathrm{kDa}$ ). Incubation with rabbit monoclonal GAPDH antibody (1:1000, Cell Signaling Technology, Inc., New England Biolabs) served as a loading control. Phospho FAK and total FAK bands were detected using horseradish peroxidase-labeled anti-rabbit antibody (1:3000, Goat Anti-Rabbit IgG peroxidase conjugate (Pierce) and a Western Sure Premium Chemiluminescent Substrate (LI-COR, USA). Specific bands were quantified by LI-COR Image Studio software (Licor, USA). Levels of each protein were expressed as the ratio of signal intensity for the target protein relative to that of GAPDH $[24,26]$.

\section{Confocal laser scanning immunofluorescence microscopy}

For immunofluorescence laser scanning microscopy DU-145 cells, incubated with 1.25 or $2.5 \mu \mathrm{M}$ istaroxime, or DMSO respectively for the indicated time scales, were grown on glass chamber slides (Sarstedt, Germany), washed twice with PBS and fixed with 4\% PFA for 15 min at room temperature. Subsequently, the cells were incubated for 1 hour at room temperature in blocking buffer containing 3\% BSA (in PBS) and exposed overnight at $4^{\circ} \mathrm{C}$ with rabbit polyclonal Orai1 antibody (1:200, Alomone labs). After three washing steps with PBS the cells were incubated with FITC labeled goat anti-rabbit secondary antibody (1:1000, Invitrogen) for $1 \mathrm{~h}$ at room temperature. Following three washes with PBS all slides were mounted with ProLong Gold antifade reagent (Life Technologies, USA). Images were subsequently taken on a Zeiss LSM5 EXCITER Confocal Laser Scanning Microscope (Carl Zeiss Micro Imaging) with an A-Plan 40× ocular.

\section{$\mathrm{Ca}^{2+}$ measurements}

Fura-2 fluorescence was utilized to determine intracellular $\mathrm{Ca}^{2+}$ after treatment with and without istaroxime. Therefore cells were loaded with Fura-2/AM ( $2 \mu \mathrm{M}$, Invitrogen, Goettingen, Germany) for 20-30 $\min$ at $37^{\circ} \mathrm{C}$ and were excited alternatively at $340 \mathrm{~nm}$ and $380 \mathrm{~nm}$ through an objective (Fluor $40 \times / 1.30$ oil) built in an inverted fluorescence microscope (Axiovert 100, Zeiss, Oberkochen, Germany). Emitted fluorescence intensity was recorded at $505 \mathrm{~nm}$ and the data were acquired using specialized computer software (Metafluor, Universal Imaging, Downingtown, USA). Cytosolic $\mathrm{Ca}^{2+}$ activity was estimated from the $340 \mathrm{~nm} / 380 \mathrm{~nm}$ ratio. SOCE was determined by extracellular $\mathrm{Ca}^{2+}$ removal and subsequent $\mathrm{Ca}^{2+}$ re-addition in the presence of thapsigargin $\left(1 \mu \mathrm{M}\right.$, Invitrogen) [27]. For quantification of $\mathrm{Ca}^{2+}$ entry, the slope (delta ratio/s) and peak (delta ratio) were calculated following re-addition of $\mathrm{Ca}^{2+}[28,29]$.

Experiments were performed with Ringer solution containing (in mM): $125 \mathrm{NaCl}, 5 \mathrm{KCl}, 1.2 \mathrm{MgSO}_{4}, 2$ $\mathrm{CaCl}_{2}, 2 \mathrm{Na}_{2} \mathrm{HPO}_{4}, 32$ HEPES, 5 glucose, $\mathrm{pH}$ 7.4. To reach nominally $\mathrm{Ca}^{2+}$-free conditions, experiments were performed using $\mathrm{Ca}^{2+}$-free Ringer solution containing (in $\mathrm{mM}$ ): $125 \mathrm{NaCl}, 5 \mathrm{KCl}, 1.2 \mathrm{MgSO}_{4}, 2 \mathrm{Na}_{2} \mathrm{HPO}_{4}, 32$ 
HEPES, 0.5 EGTA, 5 glucose, $\mathrm{pH}$ 7.4. In the DU-145 experiments, cells were treated with istaroxime $(1.25 \mu \mathrm{M})$ for 4 hours before the experiment.

\section{In vitro migration assays}

For wound healing assays, $3 \times 10^{5}$ cells per well were plated onto 12 -well dishes. A single scratch wound was inflicted using a micropipette tip in each confluent monolayer. Cells were washed with PBS to remove cell debris, supplemented with vehicle (control) or istaroxime $(5 \mu \mathrm{M})$ and monitored. Images were captured by phase microscopy using a $10 \mathrm{x}$ objective lens at $0,4 \mathrm{~h}, 7 \mathrm{~h}$ and $10 \mathrm{~h}$ post wounding. Wound width was measured using image J analysis software and expressed as percentage of the initial wound width.

For transwell migration assays, transwell inserts with a pore diameter size of $8 \mu \mathrm{m}$ (BD Bioscience) were used. The transwells were placed in a 24-well cell culture plate containing cell culture medium with $10 \%$ fetal bovine serum as chemoattractant $(750 \mu \mathrm{l})$. The upper chambers were filled with $500 \mu \mathrm{l}$ of cell culture serum-free medium containing DU-145 cells in a concentration of $8 \times 10^{4}$ cells/well. The cells were incubated during experiment with istaroxime $(1.25$ and $2.5 \mu \mathrm{M})$ with and without 2 -APB $(5 \mu \mathrm{M})$ or PF$00562271(2 \mu \mathrm{M})$ for $24 \mathrm{~h}$ in a humidified atmosphere of $37^{\circ} \mathrm{C}$ and $5 \% \mathrm{CO}_{2}$. Cells that did not migrate through the pores of the transwell membrane were removed by a cotton swab and washing with PBS. The transwells were moved to $70 \%$ ethanol, incubated for $10 \mathrm{~min}$ at room temperature for fixation. After staining with $0.2 \%$ crystal violet for $10 \mathrm{~min}$ the membranes were washed twice with water. Membranes were removed by scalpel, placed on slides and analyzed. The migrated cells bound on the lower surface to the membrane were then counted at 3 different representative areas using Axio Vision Release 4.8 software (Carl Zeiss Vision, Oberkochen, Germany).

\section{Statistics}

GraphPad Prism 4 (GraphPad Software, La Jolla, CA, USA) was used for statistical analyses. All data were tested for significance using unpaired Student $t$-test or ANOVA (Bonferroni test, Dunnett test). Only results with $\mathrm{p}<0.05$ were considered statistically significant. Data are presented as means \pm standard deviation (SD) unless otherwise specified. All experiments were performed in at least 3 independent replications.

\section{Results}

Istaroxime inhibits migration of DU-145 prostate cancer cells

We first addressed the efficacy of istaroxime to influence the migration potential of DU145 prostate cancer cells by using two distinct techniques, the wound healing- and transwellassays. As shown in Figure 1A, treatment of the cells with $5 \mu \mathrm{M}$ istaroxime significantly inhibited cell motility, manifested by the diminished wound width as compared to control untreated cells (Fig. 1B). This finding was fully supported by the transwell assay, showing

Fig. 1. Istaroxime inhibits cell motility. A uniform scratch was made in each confluent monolayer culture in the absence (control) or presence of istaroxime $(5 \mu \mathrm{M})(\mathrm{A}, \mathrm{B})$. Wound area, at the indicated time points, was expressed as a percentage of the initial wound area (B). Transwell assay: Arithmetic means \pm SD $(n=4)$ of the percentage migrated DU-145 cells in the absence (white bar) and presence of istaroxime (1.25 and $2.5 \mu \mathrm{M}, 24 \mathrm{~h}$ ) (black bars) and

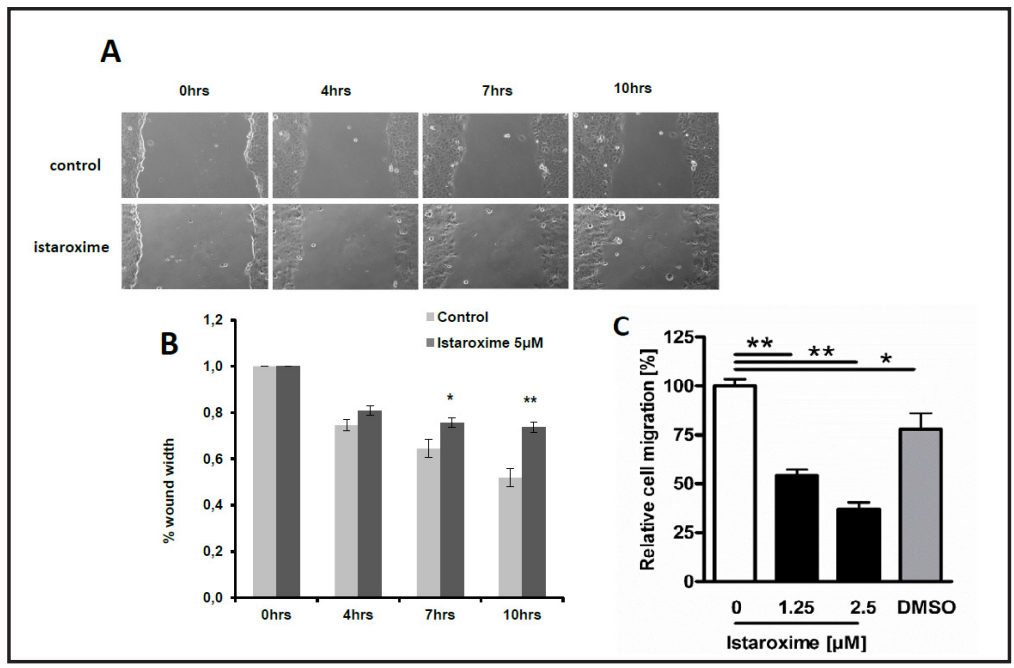
solvent DMSO (grey bar) (C). Significantly different from control $\left(^{*} p \leq 0.05,{ }^{* *} p \leq 0.01\right.$ ). 
potent inhibition of $24 \mathrm{~h}$ cell migration potential, even at lower istaroxime concentrations (Fig. 1C).

\section{Istaroxime down-regulates Orai1/Stim1 expression and store operated $\mathrm{Ca}^{2+}$ entry}

Having established the anti-migratory potential of istaroxime we further addressed possible mechanisms that may contribute to this effect. We first focused on the impact of istaroxime on Orai1, Stim1 expression and store operated $\mathrm{Ca}^{2+}$ entry (SOCE). As illustrated in Figure 2A, B, RT-PCR analysis showed significant decrease in Orai 1 and Stim1 transcript levels in istaroxime treated DU-145 cells that was evident after 4 hours and reached statistical significance after 6 hours treatments. In line with this finding, confocal laser scanning microscopy revealed significantly diminished expression of Orai1 protein levels in DU-145 cells treated with 1.25 and $2.5 \mu \mathrm{M}$ istaroxime for 6 hours (Fig. 3A, B). As illustrated further in Figure 4, 4 hours istaroxime-treatment significantly decreased the peak of store operated $\mathrm{Ca}^{2+}$ entry (SOCE) that was triggered by depletion of $\mathrm{Ca}^{2+}$ stores with thapsigargin, a well-established inhibitor of sarcoendoplasmatic reticulum $\mathrm{Ca}^{2+}$ ATPase.

\section{Istaroxime controls FAK de-phosphorylation}

In addition to the aforementioned analyses, we have also addressed the influence of istaroxime on Focal Adhesion Kinase (FAK) phosphorylation. FAK and its downstream signaling activators PI3K/Rac1/Akt/SGK1 regulate cell survival maintenance [30-35] while deactivation of FAK induces loss of substrate adhesion, triggers apoptotic responses and inhibits migration [36-41]. As shown in Figure 5, the ratio of phosphorylated FAK to the total FAK protein decreased significantly after $2 \mathrm{~h}$ treatment of DU-145 cells with 1.25 and $2.5 \mu \mathrm{M}$ istaroxime, while longer incubation time revealed total de-phosphorylation of this protein, indicating strong kinase deactivation. Although degradation of p-FAK or phosphatases

Fig. 2. Istaroxime downregulates Orai1/Stim1 transcript levels. Arithmetic means \pm SD $(n=3)$ of Orai1 (A) and STIM1 (B) transcript levels relative to TBP in DU145 cells treated with 1.25 or $2.5 \mu \mathrm{M}$ istaroxime for 4 or 6 hours. Significantly different from control $\left(^{*} \mathrm{p} \leq 0.05\right.$, $* * \mathrm{p} \leq 0.01$ ).

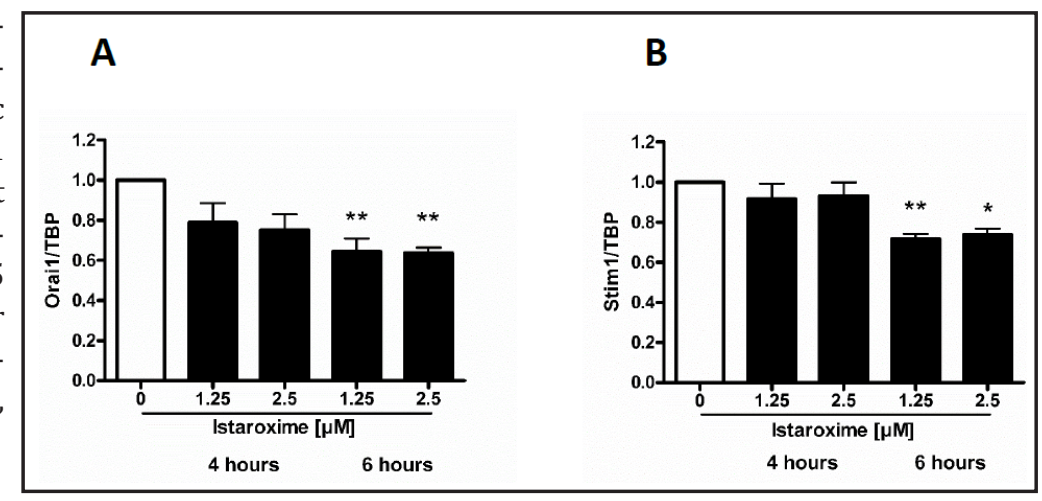

Fig. 3. Istaroxime down-regulates the Orai1 protein abundance of DU-145 cell line. A) Confocal microscopy of Orai1 protein abundance in DU-145 cells after treatment without and with 1.25 or $2.5 \mu \mathrm{M}$ istaroxime and DMSO for 6 hours. Scale bar represents 10 $\mu \mathrm{m}$. (B) Statistical analysis of Orai1 immunofluorescence abundance without (white symbol) and with (black symbols) 1.2 or $2.5 \mu \mathrm{M}$ istaroxime and solvent DMSO (grey bar) after 6 hours treatment. ${ }^{* *}(\mathrm{p}<0.01)$; $* * * *(\mathrm{p}<0.0001)$ indicates statistical significance from untreated cells.

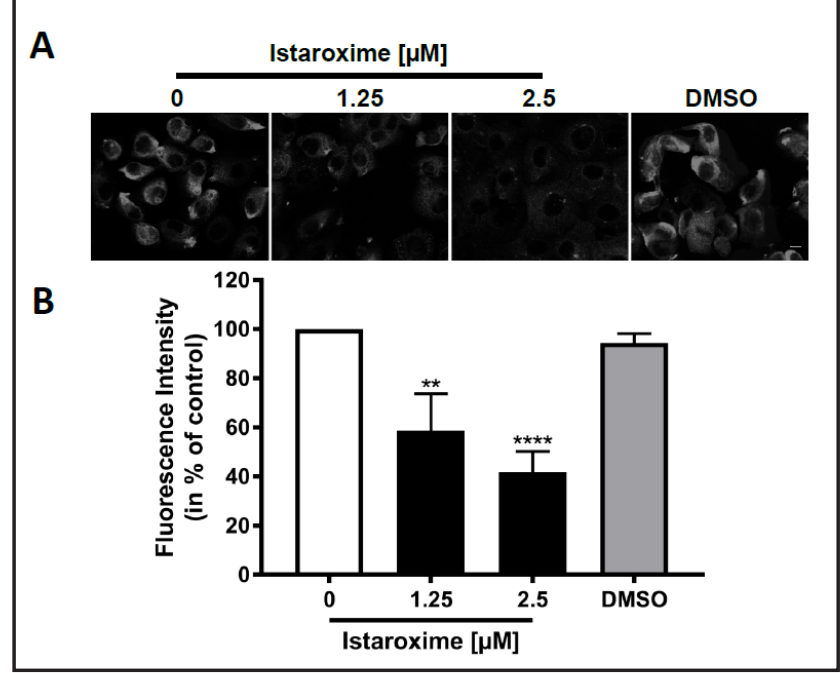


A

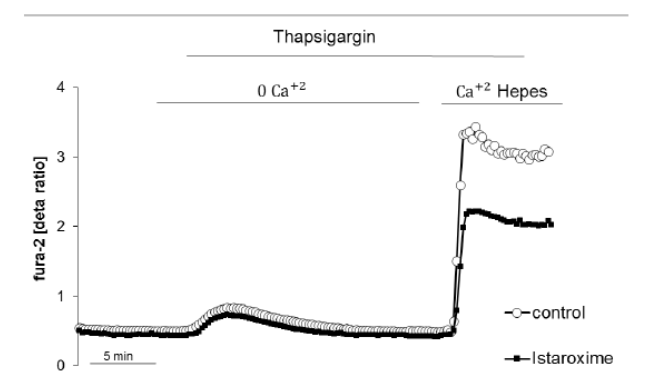

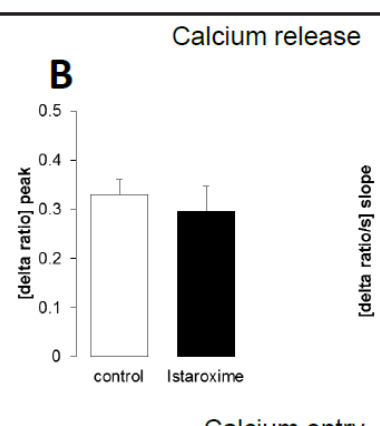

Calcium entry

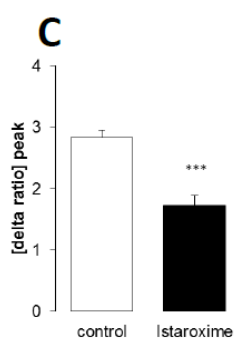

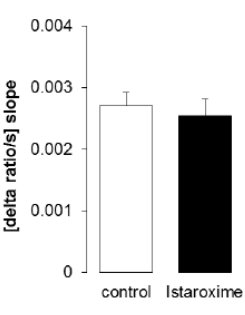

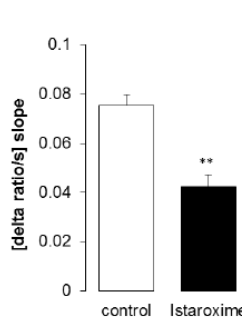

Fig. 4. Istaroxime down-regulates store operated $\mathrm{Ca}^{2+}$ entry. A) Representative tracings of Fura-2 fluorescence-ratio in fluorescence spectrometry before and following extracellular $\mathrm{Ca}^{2+}$ removal and addition of thapsigargin $(1 \mu \mathrm{M})$, as well as re-addition of extracellular $\mathrm{Ca}^{2+}$ without (white symbols) and with (black symbols) after 4 hours with $1.25 \mu \mathrm{M}$ istaroxime treatment $B$, C. Arithmetic means $( \pm$ SEM, $n=5)$ of peak (left) and slope (right) increase of fura-2-fluorescence-ratio from intracellular stores (B) and upon SOCE (C) following addition of thapsigargin $(1 \mu \mathrm{M})$ in DU-145 cells without (white bars) and with (black bars) prior istaroxime treatment for 4 hours. ${ }^{* * *}(\mathrm{p}<0.001)$ indicates statistically significant difference from untreated cells (two-tailed unpaired $t$-test).

Fig. 5. Istaroxime controls FAK de-phosphorylation. A) Original Western blot of the expression of phosphorylated FAK (upper panel), total FAK protein (middle panel) and GAPDH protein (lower panel) in DU-145 cells treated with 1.25 and $2.5 \mu \mathrm{M}$ istaroxime for 2, 4 and 6 hours. (B) Arithmetic means \pm SD ( $n=4$ independent experiments) of phosphorylated (Y397) over total FAK protein abundance in DU-145 cells treated without (white bar) or with istaroxime $(1.25$ or $2.5 \mu \mathrm{M})$ for 2 hours (black bars). Significantly different from control $\left({ }^{* * *} \mathrm{p} \leq 0.001\right)$.

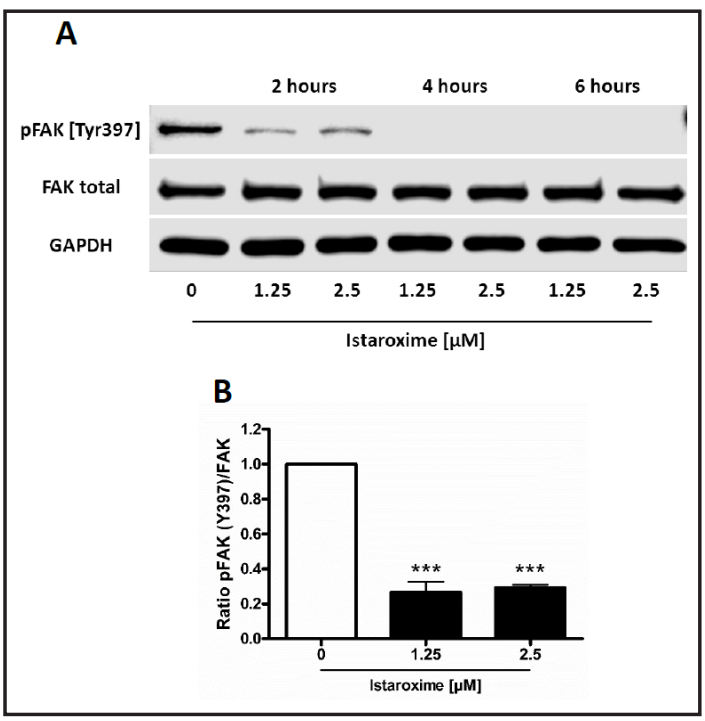

induction by istaroxime were not evaluated in this study, the dramatic decrease of phosphorylated protein fraction indicates rather a significant deactivation of this kinase that is controlling the observed anti tumorigenic effects of this compound.

Orai1/SOCE and FAK inhibition promote anti-migratory effects of istaroxime

We further evaluated the significance of Orai1/SOCE and FAK on the istaroxime-initiated inhibition of cell motility. To this end, DU-145 cells were pre-treated with the specific Orai1 and FAK inhibitors 2-APB and PF-00562271 respectively. As illustrated in Figure 6, the 


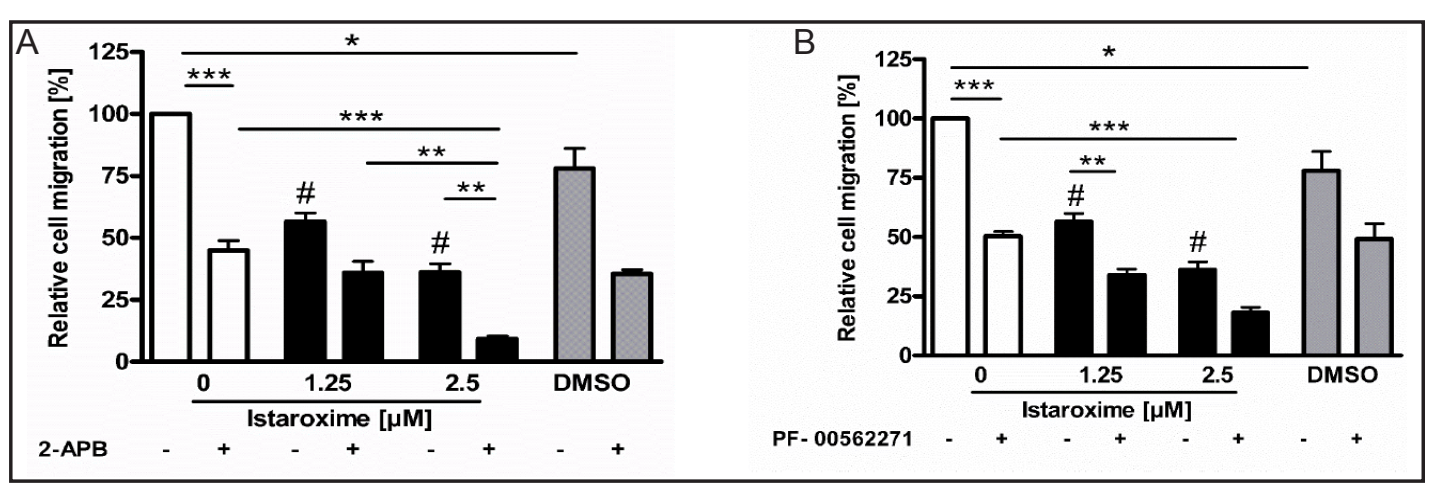

Fig. 6. Orai1/SOCE and FAK inhibition promote anti-migratory efficacy of istaroxime in DU-145 prostate cancer cells. Arithmetic means \pm SD $(n=3)$ of the percentage migrated DU-145 cells in the absence (white bars) and presence of istaroxime (1.25 and $2.5 \mu \mathrm{M}, 24 \mathrm{~h}$ ) (black bars) and solvent DMSO (grey bars) with and without (A) 2-APB $(5 \mu \mathrm{M})$ or (B) PF-00562271 $(2 \mu \mathrm{M})$. $^{*}(\mathrm{p}<0.05),{ }^{* *}(\mathrm{p}<0.01) ;{ }^{* * *}(\mathrm{p}<0.001)$ indicates statistical significance; \# indicates statistically significant difference from untreated cells $* * *(\mathrm{p}<0.001)$.

inhibitory effect of istaroxime on DU-145 cell migration was further substantially enhanced by blocking Orai1 and FAK by the specific inhibitors 2-ABP and PF-00562271 respectively.

\section{Discussion}

Apart from its well documented cardiac role, $\mathrm{Na}^{+} / \mathrm{K}^{+}$ATPase is also emerging as a promising novel anti-cancer target [reviewed in [4]]. Previous studies from our group established effective anti-cancer activity of various $\mathrm{Na}^{+} / \mathrm{K}^{+}$ATPase inhibitors in multiple cancer cell lines $[8,9,42]$, while in vivo studies in prostate and lung cancer xenografts showed potent, dose dependent tumor inhibition properties [9]. In line with these reports, istaroxime, the lead molecule of this class of $\mathrm{Na}^{+} / \mathrm{K}^{+}$ATPase inhibitors $[1-3,6]$, showed strong activity in multiple cancer cell lines derived from a large variety of tumor panels in vitro as well as in prostate cancer xenografts in vivo [10]. In this study it was demonstrated that istaroxime was inducing apoptosis, caspase-3 activation, down-regulation of c-Myc oncoprotein, actin reorganization and rapid activation of RhoA signaling [10]. These findings recognized a crucial anti-cancer potential of this compound. In agreement with these reports, the results presented here disclose an additional functional role of istaroxime in other key tumor specific mechanisms, namely migration and cell motility. These effects were documented by using two distinct approaches, confirming the anti-tumorigenic activity of this compound. They are also in accord with recently published observations, demonstrating inhibition of breast cancer cell migration by the cardiac glycoside digoxin, a classical $\mathrm{Na}^{+} / \mathrm{K}^{+}$ ATPase inhibitor [43].

Furthermore, looking for molecular mediators triggered by istaroxime and controlling inhibition of migration, we recognized for the first time istaroxime-induced down-regulation of Orai1/Stim 1 expression and significant decrease of store operated $\mathrm{Ca}^{2+}$ entry (SOCE), assessed by the Fura- 2 fluorescence of Fura-2-AM loaded DU-145 cells that was taken as a measure of cytosolic calcium concentration $\left(\left[\mathrm{Ca}^{2+}\right]_{\mathrm{i}}\right)[21]$. These findings imply the involvement of cytosolic $\mathrm{Ca}^{2+}$ activity, regulated by the pore forming $\mathrm{Ca}^{2+}$ channel subunit Orai 1 in controlling prostate tumor cell migration upon istaroxime treatment, further confirming previous observations in various cancer cell types [5, 11, 44-48].

FAK signaling has also been reported to control cell survival and migration in various tumor cells [36-38, 49, 50]. Our findings showing strong de-phosphorylation of this kinase by istaroxime fully support these reports and imply that FAK deactivation, besides Orai1/SOCE down-regulation, may contribute to the observed istaroxime-induced inhibition of DU-145 prostate cell migration. This assumption is further supported by the enhanced istaroximeinduced inhibition of migration in the presence of the Orai1 and FAK inhibitors. 
We have previously profiled istaroxime against a panel of 22 different cancer cells from 9 tumor panels [10]. The average $\mathrm{GI}_{50}$ (compound concentration to suppress growth by $50 \%$ ) in those cell lines was $4 \mu \mathrm{M}$, while in the prostate cell lines the compound's average $\mathrm{GI}_{50}$ was $2.5 \mu \mathrm{M}$. Based on these findings we have used concentrations of $1.25,2.5$ and $5 \mu \mathrm{M}$ in all our assays, i.e. concentrations that fit the compound's $\mathrm{GI}_{50^{\circ}}$. In addition, taking into account istaroxime's $\mathrm{Na}^{+} / \mathrm{K}^{+}$ATPase inhibitor $\mathrm{IC}_{50}$ of $\sim 0.4 \mu \mathrm{M}$, our applied concentrations both, in previously published cancer studies as well as in this work, are up to 10x fold higher than the compound's target $\mathrm{IC}_{50}$; this is in agreement with standard practice in order to sufficiently hit the molecular target and induce a possible effect over the time course of a given assay.

It was previously reported that the $\mathrm{Na}^{+} / \mathrm{K}^{+}$ATPase inhibitor istaroxime may exert functional cross talk with $\mathrm{mAR}$ [10], a membrane androgen receptor mediating rapid, nongenomic anti-cancer effects of androgens in multiple cancer cells [34, 40, 51-59]. Although it was supposed that $\mathrm{Na}^{+} / \mathrm{K}^{+}$ATPase and mAR are not identical [10], based on the similarity of the downstream signaling events triggered by istaroxime $[9,10]$ and mAR activation [summarized in [55] and [23]] it was assumed that $\mathrm{Na}^{+} / \mathrm{K}^{+}$ATPase and mAR may be functionally interlinked [10]. The results of the present study further support this notion. Indeed, mAR activation by testosterone conjugates in prostate, breast and colon tumor cells was previously reported to inhibit migration and induce potent pro-apoptotic responses, effects that were regulated -among others- by Orai1 expression [20], SOCE [20] and FAK deactivation $[38,50,60]$. Interestingly, in the present study these signaling effectors are shown to be implicated as well in the istaroxime-induced anti-migratory effects, implying once again, a possible functional cross-talk between $\mathrm{Na}^{+} / \mathrm{K}^{+}$ATPase and mAR. Further studies are now required to analyze this interaction in more detail.

To conclude, in the present study we demonstrate for the first time that istaroxime, a clinically validated $\mathrm{Na}^{+} / \mathrm{K}^{+}$ATPase inhibitor that is functionally interlinked with mAR, exerts potent inhibition of cell migration in prostate cancer cells, by and at least partially due to down-regulation of Orai1/Stim1 expression, decrease of store operated $\mathrm{Ca}^{2+}$ entry (SOCE) and de-phosphorylation of FAK. These findings reinforce the anti-tumorigenic properties of this compound providing additional insights in the molecular signaling involved.

\section{Acknowledgements}

This study was supported by the International Scientific Partnership Program ISPP at King Saud University (KSU-ISPP\#009), the Deutsche Forschungsgemeinschaft (Mercator Professorship Program) and the Open Access Publishing Fund of Tuebingen University. The authors acknowledge the meticulous preparation of the manuscript by Lejla Subasic and Elina Valourdou. The authors also thank Dr. Andreas Mack for providing outstanding technical support in the confocal microscopy.

\section{Discloser Statement}

The authors declare that they do not have any conflicts to state.

\section{References}

Shah SJ, Blair JE, Filippatos GS, Macarie C, Ruzyllo W, Korewicki J, Bubenek-Turconi SI, Ceracchi M, Bianchetti M, Carminati P, Kremastinos D, Grzybowski J, Valentini G, Sabbah HN, Gheorghiade M, Investigators $\mathrm{H}-\mathrm{H}$ : Effects of istaroxime on diastolic stiffness in acute heart failure syndromes: results from the Hemodynamic, Echocardiographic, and Neurohormonal Effects of Istaroxime, a Novel Intravenous Inotropic and Lusitropic Agent: a Randomized Controlled Trial in Patients Hospitalized with Heart Failure (HORIZON-HF) trial. Am Heart J 2009;157:1035-1041. 


\section{Cellular Physiology Cell Physiol Biochem 2017;42:1366-1376 \begin{tabular}{l|l} 
DOI: 10.1159/000479200 & Ond Biochemistry \\
Published online: July 14, 2017 & $\begin{array}{l}\text { 2017 The Author(s). Published by S. Karger AG, Basel } \\
\text { www.karger.com/cpb }\end{array}$
\end{tabular}}

Stagno et al.: Istaroxime Inhibits Migration in Prostate Cancer Cells

2 Alemanni M, Rocchetti M, Re D, Zaza A: Role and mechanism of subcellular Ca2+ distribution in the action of two inotropic agents with different toxicity. J Mol Cell Cardiol 2011;50:910-918.

-3 Blair JE, Macarie C, Ruzyllo W, Bacchieri A, Valentini G, Bianchetti M, Pang PS, Harinstein ME, Sabbah HN, Filippatos GS, Gheorghiade M, investigators H-H: Rationale and design of the hemodynamic, echocardiographic and neurohormonal effects of istaroxime, a novel intravenous inotropic and lusitropic agent: a randomized controlled trial in patients hospitalized with heart failure (HORIZON-HF) trial. Am J Ther 2008;15:231-240.

-4 Alevizopoulos K, Calogeropoulou T, Lang F, Stournaras C: Na+/K+ ATPase inhibitors in cancer. Curr Drug Targets 2014;15:988-1000.

5 Lang F, Stournaras C: Ion channels in cancer: future perspectives and clinical potential. Philos Trans R Soc Lond B Biol Sci 2014;369:20130108.

6 De Munari S, Cerri A, Gobbini M, Almirante N, Banfi L, Carzana G, Ferrari P, Marazzi G, Micheletti R, Schiavone A, Sputore S, Torri M, Zappavigna MP, Melloni P: Structure-based design and synthesis of novel potent $\mathrm{Na}+, \mathrm{K}+-$ ATPase inhibitors derived from a 5alpha,14alpha-androstane scaffold as positive inotropic compounds. J Med Chem 2003;46:3644-3654.

7 Micheletti R, Mattera GG, Rocchetti M, Schiavone A, Loi MF, Zaza A, Gagnol RJ, De Munari S, Melloni P, Carminati P, Bianchi G, Ferrari P: Pharmacological profile of the novel inotropic agent (E,Z)-3((2-aminoethoxy)imino)androstane-6,17-dione hydrochloride (PST2744). J Pharmacol Exp Ther 2002;303:592-600.

8 Dimas K, Papadopoulou N, Baskakis C, Prousis KC, Tsakos M, Alkahtani S, Honisch S, Lang F, Calogeropoulou T, Alevizopoulos K, Stournaras C: Steroidal cardiac Na+/K+ ATPase inhibitors exhibit strong anti-cancer potential in vitro and in prostate and lung cancer xenografts in vivo. Anticancer Agents Med Chem 2014;14:762-770.

-9 Honisch S, Alkahtani S, Kounenidakis M, Liu G, Alarifi S, Al-Yahya H, Dimas K, AlKahtane AA, Prousis KC, AlDahmash B, Calogeropoulou T, Alevizopoulos K, Lang F, Stournaras C: A steroidal Na+/K+ ATPase inhibitor triggers pro-apoptotic signaling and induces apoptosis in prostate and lung tumor cells. Anticancer Agents Med Chem 2014;14:1161-1168.

10 Alevizopoulos K, Dimas K, Papadopoulou N, Schmidt EM, Tsapara A, Alkahtani S, Honisch S, Prousis KC, Alarifi S, Calogeropoulou T, Lang F, Stournaras C: Functional characterization and anti-cancer action of the clinical phase II cardiac $\mathrm{Na}+\mathrm{K}+$ ATPase inhibitor istaroxime: in vitro and in vivo properties and cross talk with the membrane androgen receptor. Oncotarget 2016;7:24415-24428.

11 Becchetti A, Arcangeli A: Integrins and ion channels: molecular complexes and signaling. Adv Exp Med Biol 2010;674:v-vii.

12 Roderick HL, Cook SJ: Ca2 + signalling checkpoints in cancer: remodelling Ca2 + for cancer cell proliferation and survival. Nat Rev Cancer 2008;8:361-375.

13 Lang F, Hoffmann EK: Role of ion transport in control of apoptotic cell death. Compr Physiol 2012;2:20372061.

14 Prakriya M, Feske S, Gwack Y, Srikanth S, Rao A, Hogan PG: Orai1 is an essential pore subunit of the CRAC channel. Nature 2006;443:230-233.

15 Putney JW, Jr: New molecular players in capacitative Ca2+ entry. J Cell Sci 2007;120:1959-1965.

-16 Vig M, Peinelt C, Beck A, Koomoa DL, Rabah D, Koblan-Huberson M, Kraft S, Turner H, Fleig A, Penner $\mathrm{R}$, Kinet JP: CRACM1 is a plasma membrane protein essential for store-operated Ca2+ entry. Science 2006;312:1220-1223.

17 Zhang SL, Kozak JA, Jiang W, Yeromin AV, Chen J, Yu Y, Penna A, Shen W, Chi V, Cahalan MD: Store-dependent and -independent modes regulating $\mathrm{Ca} 2+$ release-activated $\mathrm{Ca} 2+$ channel activity of human Orai1 and Orai3. J Biol Chem 2008;283:17662-17671.

18 Schmidt S, Liu G, Liu G, Yang W, Honisch S, Pantelakos S, Stournaras C, Honig A, Lang F: Enhanced Orai1 and STIM1 expression as well as store operated Ca2+ entry in therapy resistant ovary carcinoma cells. Oncotarget 2014;5:4799-4810.

19 Zhu H, Zhang H, Jin F, Fang M, Huang M, Yang CS, Chen T, Fu L, Pan Z: Elevated Orai1 expression mediates tumor-promoting intracellular Ca2+ oscillations in human esophageal squamous cell carcinoma. Oncotarget 2014;5:3455-3471.

20 Liu G, Honisch S, Liu G, Schmidt S, Alkahtani S, AlKahtane AA, Stournaras C, Lang F: Up-regulation of Orai1 expression and store operated $\mathrm{Ca}(2+)$ entry following activation of membrane androgen receptors in MCF7 breast tumor cells. BMC Cancer 2015;15:995. 


\section{Cellular Physiology Cell Physiol Biochem 2017;42:1366-1376 \begin{tabular}{l|l} 
DOI: 10.1159/000479200 & Ond Biochemistry \\
Published onlne: July 14, 2017 & $\begin{array}{l}\text { 2017 The Author(s). Published by S. Karger AG, Basel } \\
\text { www.karger.com/cpb }\end{array}$
\end{tabular}}

Stagno et al.: Istaroxime Inhibits Migration in Prostate Cancer Cells

21 Yu W, Honisch S, Schmidt S, Yan J, Schmid E, Alkahtani S, AlKahtane AA, Alarifi S, Stournaras C, Lang F: Chorein Sensitive Orai1 Expression and Store Operated Ca2+ Entry in Rhabdomyosarcoma Cells. Cell Physiol Biochem 2016;40:1141-1152.

22 Schmid E, Stagno MJ, Yan J, Stournaras C, Lang F, Fuchs J, Seitz G: Store-operated Ca(2+) entry in rhabdomyosarcoma cells. Biochem Biophys Res Commun 2016;477:129-136.

-23 Gu S, Honisch S, Kounenidakis M, Alkahtani S, Alarifi S, Alevizopoulos K, Stournaras C, Lang F: Membrane androgen receptor down-regulates c-src-activity and beta-catenin transcription and triggers GSK-3betaphosphorylation in colon tumor cells. Cell Physiol Biochem 2014;34:1402-1412.

-24 Feger M, Fajol A, Lebedeva A, Meissner A, Michael D, Voelkl J, Alesutan I, Schleicher E, Reichetzeder C, Hocher B, Qadri SM, Lang F: Effect of carbon monoxide donor CORM-2 on vitamin D3 metabolism. Kidney. Blood Press. Res. 2013;37:496-505.

25 Papadimitriou E, Vasilaki E, Vorvis C, Iliopoulos D, Moustakas A, Kardassis D, Stournaras C: Differential regulation of the two RhoA-specific GEF isoforms Net1/Net1A by TGF-beta and miR-24: role in epithelialto-mesenchymal transition. Oncogene 2012;31:2862-2875.

26 Schmid E, Xuan NT, Zahir N, Russo A, Yang W, Kuhl D, Faggio C, Shumilina E, Lang F: Serum- and glucocorticoid-inducible kinase 1 sensitive NF-kappaB signaling in dendritic cells. Cell Physiol Biochem 2014;34:943-954.

-27 Bird GS, DeHaven WI, Smyth JT, Putney JW, Jr.: Methods for studying store-operated calcium entry. Methods 2008;46:204-212.

28 Yang W, Nurbaeva MK, Schmid E, Russo A, Almilaji A, Szteyn K, Yan J, Faggio C, Shumilina E, Lang F: Akt2- and ETS1-dependent IP3 receptor 2 expression in dendritic cell migration. Cell Physiol Biochem 2014;33:222-236.

29 Bhavsar SK, Schmidt S, Bobbala D, Nurbaeva MK, Hosseinzadeh Z, Merches K, Fajol A, Wilmes J, Lang F: AMPKalpha1-sensitivity of Orai1 and $\mathrm{Ca}(2+)$ entry in T - lymphocytes. Cell. Physiol. Biochem. 2013;32:687698.

-30 Lu Q Rounds S: Focal adhesion kinase and endothelial cell apoptosis. Microvasc Res 2012;83:56-63.

-31 Papakonstanti EA, Kampa M, Castanas E, Stournaras C: A rapid, nongenomic, signaling pathway regulates the actin reorganization induced by activation of membrane testosterone receptors. Mol Endocrinol 2003;17:870-881.

32 Hanks SK, Ryzhova L, Shin NY, Brabek J: Focal adhesion kinase signaling activities and their implications in the control of cell survival and motility. Front Biosci 2003;8:d982-996.

33 Schaller MD: Cellular functions of FAK kinases: insight into molecular mechanisms and novel functions. J Cell Sci 2010;123:1007-1013.

34 Gu S, Papadopoulou N, Gehring EM, Nasir O, Dimas K, Bhavsar SK, Foller M, Alevizopoulos K, Lang F, Stournaras C: Functional membrane androgen receptors in colon tumors trigger pro-apoptotic responses in vitro and reduce drastically tumor incidence in vivo. Mol Cancer 2009;8:114.

35 Kratimenos P, Koutroulis I, Marconi D, Syriopoulou V, Delivoria-Papadopoulos M, Chrousos GP, Theocharis S: Multi-targeted molecular therapeutic approach in aggressive neuroblastoma: the effect of Focal Adhesion Kinase-Src-Paxillin system. Expert Opin Ther Targets 2014;18:1395-1406.

-36 Chen Y, Chou WC, Ding YM, Wu YC: Caffeine inhibits migration in glioma cells through the ROCK-FAK pathway. Cell Physiol Biochem 2014;33:1888-1898.

37 Alowayed N, Salker MS, Zeng N, Singh Y, Lang F: LEFTY2 Controls Migration of Human Endometrial Cancer Cells via Focal Adhesion Kinase Activity (FAK) and miRNA-200a. Cell Physiol Biochem 2016;39:815-826.

-38 Kallergi G, Agelaki S, Markomanolaki H, Georgoulias V, Stournaras C: Activation of FAK/PI3K/Rac1 signaling controls actin reorganization and inhibits cell motility in human cancer cells. Cell Physiol Biochem 2007;20:977-986.

-39 Figel S, Gelman IH: Focal adhesion kinase controls prostate cancer progression via intrinsic kinase and scaffolding functions. Anticancer Agents Med Chem 2011;11:607-616.

40 Gu S, Papadopoulou N, Nasir O, Foller M, Alevizopoulos K, Lang F, Stournaras C: Activation of membrane androgen receptors in colon cancer inhibits the prosurvival signals Akt/bad in vitro and in vivo and blocks migration via vinculin/actin signaling. Mol Med 2011;17:48-58.

41 van Nimwegen MJ, van de Water B: Focal adhesion kinase: a potential target in cancer therapy. Biochem Pharmacol 2007;73:597-609.

42 Alkahtani SH: The steroidal Na+/K+ ATPase inhibitor 3-[(R)-3-pyrrolidinyl] oxime derivative (3-R-POD) induces potent pro-apoptotic responses in colonic tumor cells. Anticancer Res 2014;34:2967-2971. 


\section{Cellular Physiology Cell Physiol Biochem 2017;42:1366-1376

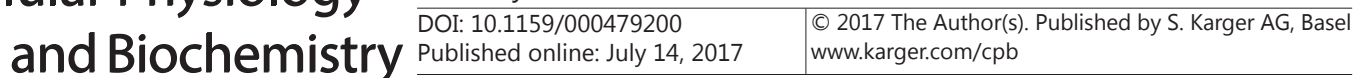

Stagno et al.: Istaroxime Inhibits Migration in Prostate Cancer Cells

43 Magpusao AN, Omolloh G, Johnson J, Gascon J, Peczuh MW, Fenteany G: Cardiac glycoside activities link $\mathrm{Na}(+) / \mathrm{K}(+)$ ATPase ion-transport to breast cancer cell migration via correlative SAR. ACS Chem Biol 2015;10:561-569.

44 Diez-Bello R, Jardin I, Salido GM, Rosado JA: Orai1 and Orai2 mediate store-operated calcium entry that regulates HL60 cell migration and FAK phosphorylation. Biochim Biophys Acta 2016;10.1016/j. bbamcr.2016.11.014

45 Yan J, Hosseinzadeh Z, Zhang B, Froeschl M, Schulze-Osthoff K, Stournaras C, Lang F: Decrease of StoreOperated $\mathrm{Ca} 2+$ Entry and Increase of $\mathrm{Na}+\mathrm{Ca} 2+$ Exchange by Pharmacological JAK2 Inhibition. Cell Physiol Biochem 2016;38:683-695.

46 Xia J, Wang H, Huang H, Sun L, Dong S, Huang N, Shi M, Bin J, Liao Y, Liao W: Elevated Orai1 and STIM1 expressions upregulate MACC1 expression to promote tumor cell proliferation, metabolism, migration, and invasion in human gastric cancer. Cancer Lett 2016;381:31-40.

47 Kim JH, Lkhagvadorj S, Lee MR, Hwang KH, Chung HC, Jung JH, Cha SK, Eom M: Orai1 and STIM1 are critical for cell migration and proliferation of clear cell renal cell carcinoma. Biochem Biophys Res Commun 2014;448:76-82.

48 Umemura M, Baljinnyam E, Feske S, De Lorenzo MS, Xie LH, Feng X, Oda K, Makino A, Fujita T, Yokoyama U, Iwatsubo M, Chen S, Goydos JS, Ishikawa Y, Iwatsubo K: Store-operated Ca2+ entry (SOCE) regulates melanoma proliferation and cell migration. PLoS One 2014;9:e89292.

49 Gueder N, Allan G, Telliez MS, Hague F, Garcia Fernandez JM, Sanchez-Fernandez EM, Ortiz-Mellet C, Ahidouch A, Ouadid-Ahidouch H: sp2 -Iminosugar alpha-Glucosidase Inhibitor 1-C-octyl-2-oxa-3oxocastanospermine Specifically Affected Breast Cancer Cell Migration through Stim1, beta1-Integrin, and FAK Signaling Pathways. J Cell Physiol 2017;10.1002/jcp.25832

50 Gu S, Kounenidakis M, Schmidt EM, Deshpande D, Alkahtani S, Alarifi S, Foller M, Alevizopoulos K, Lang F, Stournaras C: Rapid activation of FAK/mTOR/p70S6K/PAK1-signaling controls the early testosteroneinduced actin reorganization in colon cancer cells. Cell Signal 2013;25:66-73.

51 Kampa M, Kogia C, Theodoropoulos PA, Anezinis P, Charalampopoulos I, Papakonstanti EA, Stathopoulos EN, Hatzoglou A, Stournaras C, Gravanis A, Castanas E: Activation of membrane androgen receptors potentiates the antiproliferative effects of paclitaxel on human prostate cancer cells. Mol Cancer Ther 2006;5:1342-1351.

52 Papadopoulou N, Papakonstanti EA, Kallergi G, Alevizopoulos K, Stournaras C: Membrane androgen receptor activation in prostate and breast tumor cells: molecular signaling and clinical impact. IUBMB Life 2009;61:56-61.

53 Schmidt EM, Gu S, Anagnostopoulou V, Alevizopoulos K, Foller M, Lang F, Stournaras C: Serum- and glucocorticoid-dependent kinase-1-induced cell migration is dependent on vinculin and regulated by the membrane androgen receptor. FEBS J 2012;279:1231-1242.

54 Papadopoulou N, Charalampopoulos I, Alevizopoulos K, Gravanis A, Stournaras C: Rho/ROCK/actin signaling regulates membrane androgen receptor induced apoptosis in prostate cancer cells. Exp Cell Res 2008;314:3162-3174.

55 Lang F, Alevizopoulos K, Stournaras C: Targeting membrane androgen receptors in tumors. Expert Opin Ther Targets 2013;17:951-963.

56 Thomas P, Pang Y, Dong J, Berg AH: Identification and characterization of membrane androgen receptors in the ZIP9 zinc transporter subfamily: II. Role of human ZIP9 in testosterone-induced prostate and breast cancer cell apoptosis. Endocrinology 2014;155:4250-4265.

57 Berg AH, Rice CD, Rahman MS, Dong J, Thomas P: Identification and characterization of membrane androgen receptors in the ZIP9 zinc transporter subfamily: I. Discovery in female atlantic croaker and evidence ZIP9 mediates testosterone-induced apoptosis of ovarian follicle cells. Endocrinology 2014;155:4237-4249.

58 Stournaras C, Gravanis A, Margioris AN, Lang F: The actin cytoskeleton in rapid steroid hormone actions. Cytoskeleton (Hoboken) 2014;71:285-293.

59 Wang C, Liu Y, Cao JM: G protein-coupled receptors: extranuclear mediators for the non-genomic actions of steroids. Int J Mol Sci 2014;15:15412-15425.

60 Liu G, Honisch S, Liu G, Schmidt S, Pantelakos S, Alkahtani S, Toulany M, Lang F, Stournaras C: Inhibition of SGK1 enhances mAR-induced apoptosis in MCF-7 breast cancer cells. Cancer Biol Ther 2015;16:52-59. 